\title{
A KUKORICA RELATÍV KLOROFILL TARTALMA, LEVÉLTERÜLETE ÉS TERMÉSÁTLAGA KÖZÖTTI ÖSSZEFÜGGÉS VIZSGÁLATA MONOKULTÚRÁS TARTAMKÍSÉRLETBEN
}

\author{
Bencze Gábor - Futó Zoltán
}

\begin{abstract}
Absztrakt: Kísérletünket Szarvason, a Szent István Egyetem Agrár és Gazdaságtudományi Kar Galambosi kísérleti telepén végeztük. Tartamkísérletünkben a különbözö arányú $(\mathrm{N}, \mathrm{P}, \mathrm{K})$ tápelemek növényfiziológiai, termésképzési hatásait vizsgáltuk. A tényezők közötti összefüggéseket 32 tápanyag ellátási szinten mértük. Kísérletünkben vizsgáltuk a kukorica tápanyag-reakcióját a klorofill tartalom változása, a levélterület és a termésátlag alakulása szempontjából. Kísérletünkben a levélterület növekedése szoros pozitív korrelációt eredményezett a termésátlag növekedésével, valamint a kukoricalevél relatív klorofill tartalmával. A tápelemek közuil kísérletünkben a legjelentősebb pozitív hatást a nitrogén esetében mértük, a foszfor és a kálium hatásai kisebbek voltak.

Abstract: The experiment was set up at Szarvas in the experimental field of the University of Szent István, Faculty of Agricultural and Economics Studies, in Galambos. During the research, we examined the effect of various nutrients $(\mathrm{N}, \mathrm{P}, \mathrm{K})$ ratios on maize monoculture in long-term experiments. The contexts between the factors 32 nutrients we measured it on a supply level. We examined the nutrient reaction of maize on the chlorophyll content, the establishment of the leaf area and the average yield. The increase of the leaf area yielded a tight positive correlation with the increase of the average yield and the leaf relative chlorophyll content. From among the nutriment elements we measured the most considerable positive effect in the case of the nitrogen in our experiment, the effects of the phosphorus and the potassium were smaller.
\end{abstract}

Kulcsszavak: kukorica, tápanyag utánpótlás, klorofill tartalom, levélterület, termésátlag

Keywords: maize, nutrient supply, chlorophyll content, leaf area, yield

\section{Bevezetés}

Hazánkban a kukorica a legnagyobb területen termesztett szántóföldi növény. Az összes szántóterületből 26-27\%-kal részesedik. Fö felhasználási területe az állati takarmányozás, ez a szám hazánkban mintegy $90 \%$-a a termésnek. A világ népességének egyre nagyobb ütemü növekedésével azonban egyre inkább elötérbe kerül az élelmiszeripari felhasználása is.

A hazai kukoricatermesztés fejlesztése nagyban függ az alkalmazott agrotechnikától. A termésnövelés szükséges szinten tartása mellett a termésingadozás minimalizálása a cél, ebben pedig fontos szerep jut többek között a megfelelő NPK tápanyagellátásnak is.

A kukorica levele amellett, hogy a növényi biomassza jelentős hányadát képezi, illetve a fotoszintézishez szükséges fényenergiát megköti, elsődleges befolyásolója a megtermelt biomassza és termés nagyságának.

\section{Irodalmi áttekintés}

A kukorica termését számos tényező befolyásolja, mint pl. az elégtelen víz- és tápanyagellátás. Ezek a tényezők hatással vannak a kukorica levélterületére, ahol a 
fotoszintézis folyamata zajlik. Minden olyan tényező- köztük a növekvő tápanyagellátás - mely növeli a kukorica fotoszintetikusan aktív levélterületét, növeli a kukorica termését is (Futó, 2003).

A SPAD 502 klorofill mérő müszer segítségével a növény klorofill tartalmát tudjuk mérni, így információt kaphatunk a kukorica levelek aktuális $\mathrm{N}$ tartalmáról, ami segíthet meghatározni a $\mathrm{N}$ mütrágya szükségletet (Tóth et al. 2014).

Berzsenyi és Lap (2001) szerint a klorofill koncentráció a kukoricában pozitív összefüggésben van a levél nitrogén - koncentrációjával és nitrogén ellátottságával.

Széles (2008) a kukorica levelek SPAD értékei és a termés mennyisége közötti kapcsolatot vizsgálva arra a következtetésre jutott, hogy a két tényezö között közepesen szoros pozitív kapcsolat volt. Széles et al. (2011) szignifikánsan nagyobb klorofill tartalmat mért átlagos nitrogén mütrágya adagok mellett aszályos évben, mint kedvező vízellátottságú évben.

\section{Anyag és módszer}

A kísérletben három tápanyag $\mathrm{N}, \mathrm{P}$ és $\mathrm{K}$ hatását vizsgáltuk, ahol a tápanyagok három emelkedő lépcsőben lettek kijuttatva. A tápelemek azonban nem csak önmagukban, hanem a lehetö legtöbb kombinációban vizsgáltak, így az egyes tápelemek egymásra gyakorolt hatását is nyomon tudjuk követni.

A nitrogén kezelések szintjei:

- $\quad$ N0 $\quad 0 \mathrm{~kg} / \mathrm{ha} \mathrm{N}$ alaptrágyaként, majd $0 \mathrm{~kg} / \mathrm{ha} \mathrm{N}$ fejtrágyaként

- $\quad \mathrm{N} 1 \quad 50 \mathrm{~kg} / \mathrm{ha} \mathrm{N}$ alaptrágyaként, majd $20 \mathrm{~kg} / \mathrm{ha} \mathrm{N}$ fejtrágyaként

- $\mathrm{N} 2100 \mathrm{~kg} / \mathrm{ha} \mathrm{N}$ alaptrágyaként, majd $40 \mathrm{~kg} / \mathrm{ha} \mathrm{N}$ fejtrágyaként

- $\mathrm{N} 3150 \mathrm{~kg} / \mathrm{ha} \mathrm{N}$ alaptrágyaként, majd $60 \mathrm{~kg} / \mathrm{ha} \mathrm{N}$ fejtrágyaként

A foszfor kezelések szintjei:

- P0 $0 \mathrm{~kg} / \mathrm{ha} \mathrm{P}$ alaptrágyaként

- P1 $40 \mathrm{~kg} / \mathrm{ha}$ P alaptrágyaként

- P2 $80 \mathrm{~kg} / \mathrm{ha}$ P alaptrágyaként

- P3 $120 \mathrm{~kg} / \mathrm{ha} \mathrm{P}$ alaptrágyaként

A kálium kezelések szintjei:

- $\quad \mathrm{K} 0 \quad 0 \mathrm{~kg} / \mathrm{ha} \mathrm{K}$ alaptrágyaként

- $\mathrm{K} 1.60 \mathrm{~kg} / \mathrm{ha} \mathrm{P}$ alaptrágyaként

- $\mathrm{K} 2120 \mathrm{~kg} / \mathrm{ha} \mathrm{P}$ alaptrágyaként

- K3 $180 \mathrm{~kg} / \mathrm{ha} P$ alaptrágyaként

A kísérleti parcellák méret $4 \mathrm{~m}$ x $5 \mathrm{~m}$. Az $5 \mathrm{~m}$-es parcella szélesség lehetővé teszi, hogy mindegyikben $76 \mathrm{~cm}$-es sortávolsággal vetve 6 sor kapjon helyet. A vetést szántóföldi pneumatikus szemenkénti vetőgéppel végeztük a kísérleti terület egészére, melyből a kelés után utakat marózunk ki, kialakítva ezzel a parcellákat. A tőtávolságot $17,8 \mathrm{~cm}$-ben határoztuk meg, mely hozzávetőleg $75000 \mathrm{csíra} / \mathrm{ha-t}$ jelent. A 6 sorból 2-t tekinthetünk szegélysornak, elkerülve az esetleges mütrágya átfedéseket a parcellák között. A vizsgálatokhoz szükséges mintákat, melyek „roncsolással” járnak a 2. és az 5 . sorból vettük, míg a betakarítást és az egyéb méréseket a két középső sorban végeztük. A betakarítás kézi erővel történt. 
A korábbi szelvényfeltárások és talajvizsgálatok szerint a kísérleti terület talaja mélyben karbonátos csernozjom réti talaj. A kísérlet talajának föbb jellemzöit az elvégzett talajvizsgálatok alapján (l. táblázat) az alábbiakban foglalhatók össze.

A vizsgálataink során a szántóföldi kísérletből a mintavételek során begyüjtött levélmintákat a laborban Eijkelkamp levélterület mérö eszközünkkel mértük. A kukorica levélterületének nagyságán kívül a levél klorofill tartalma is meghatározza a kukorica szervesanyag termelését, annak produkcióját. A kukorica leveleinek klorofill tartalmának méréséhez egy hordozható Minolta SPAD fotoszintetikus pigmenttartalom-mérö müszert használtunk.

A talajvizsgálatok szerint a talaj fizikai félesége agyagos vályog, kémhatása savanyú, a müvelt réteg $\mathrm{CaCO}_{3}$-ot nem tartalmaz, a humusztartalom alapján a talaj $\mathrm{N}$-szolgáltatása közepes, a P-ellátottsága túlzott, K-ellátottsága jó, Mg-ból jól, Znből igen jól, míg Cu-ből és Mn-ból kielégítően ellátott.

\section{1. táblázat: A kukorica kísérlet talajának jellemzői}

(Szarvas, 0-30 cm-es talajréteg)

\begin{tabular}{|c|c|c|c|c|c|c|c|c|c|}
\hline $\begin{array}{c}\mathrm{pH} \\
\mathrm{KCl}\end{array}$ & $\mathrm{K}_{\mathrm{A}}$ & $\begin{array}{c}\mathrm{Ca} \\
\mathrm{CO}\end{array}$ & $\begin{array}{c}\text { Humusz } \\
(\%)\end{array}$ & $\begin{array}{c}\mathrm{AL}- \\
\mathrm{P}_{2} \mathrm{O}_{5} \\
\mathrm{mgkg}^{-1}\end{array}$ & $\begin{array}{c}\mathrm{AL}- \\
\mathrm{K}_{2} \mathrm{O} \\
\mathrm{mgkg}^{-1}\end{array}$ & $\begin{array}{c}\mathrm{Mg} \\
(\mathrm{KCl}) \\
\mathrm{mgkg}^{-1}\end{array}$ & $\begin{array}{c}\text { EDTA } \\
-\mathrm{Zn} \\
\mathrm{mgkg}^{-1}\end{array}$ & $\begin{array}{c}\text { EDTA- } \\
\mathrm{Cu} \\
\mathrm{mgkg}^{-1}\end{array}$ & $\begin{array}{c}\text { EDTA- } \\
\mathrm{Mn} \\
\mathrm{mgkg}^{-1}\end{array}$ \\
\hline 4,91 & 43,6 & 0,0 & 2,94 & 211 & 255 & 697 & 3,16 & 7,41 & 437 \\
\hline
\end{tabular}

Forrás: A szerzö saját szerkesztése

A 2016. évben január és szeptember között lehullott csapadékmennyisége 38,6 mm-el volt több mint a sokéves átlag. A szeptemberi hónap csapadéka $33 \mathrm{~mm}$-rel elmaradt a 30 éves átlagtól, ami a kialakult nagy termések vízleadását, érését segítette.

2. táblázat: Időjárási adatok a 2016. január - szeptember, Szarvas

\begin{tabular}{|c|c|c|c|c|c|c|c|c|c|c|}
\hline hónap (1) & jan. & febr. & márc. & ápr. & máj. & jún. & júl. & aug. & szept. & $\begin{array}{c}\text { összeg } \\
\text { /átlag }\end{array}$ \\
\hline $\begin{array}{c}\text { Hómérséklet }\left({ }^{\circ} \mathbf{C}\right) \\
(\mathbf{2})\end{array}$ & $-0,9$ & 6,0 & 7,3 & 13,4 & 16,6 & 21,3 & 22,5 & 21,1 & 18,3 & 13,9 \\
\hline $\begin{array}{c}\text { Csapadék (mm) } \\
(\mathbf{3})\end{array}$ & 61,6 & 88,5 & 20,0 & 12,3 & 18,8 & 124,4 & 124,4 & 50,5 & 9,8 & 448,7 \\
\hline $\begin{array}{c}\text { 30 éves } \\
\text { csapadékátlag } \\
\text { (mm) (4) }\end{array}$ & 30,6 & 31,4 & 28,9 & 41,9 & 62,9 & 71,4 & 74,4 & 56,4 & 42,8 & 410,1 \\
\hline Eltérés (mm) (5) & $\mathbf{3 1 , 0}$ & $\mathbf{5 7 , 1}$ & $\mathbf{- 8 , 9}$ & $\mathbf{- 2 9 , 6}$ & $\mathbf{- 4 4 , 1}$ & $\mathbf{5 3 , 0}$ & $\mathbf{5 0}$ & $\mathbf{- 5 , 9}$ & $\mathbf{- 3 3 , 0}$ & $\mathbf{3 8 , 6}$ \\
\hline
\end{tabular}

Forrás: A szerző saját szerkesztése

\section{Eredmények és értékelésïk}

A kukorica levelek relatív klorofill tartalmát négy egymást követö alkalommal a növény fenológiai fázisaihoz igazítva mértük, minden esetben ugyanazon a csőlevélen. A leveleken áthaladó infravörös fény segítségével számszerüsíthető információhoz (SPAD érték) jutunk. A SPAD érték egy dimenzió nélküli szám, amely a 
levél klorofill tartalmára adhat egyértelmủ adatokat. Az első mérés alkalmával kapott eredmények alapján a következő SPAD értékeket kaptuk a kísérletben.

3. táblázat: A különböző NPK tápanyagszinteken mért SPAD értékek 2016.

\begin{tabular}{|c|c|c|c|c|c|}
\hline $\begin{array}{c}\text { Nitrogén } \\
\text { szint }\end{array}$ & $\begin{array}{c}\text { SPAD } \\
\text { értékek }\end{array}$ & $\begin{array}{c}\text { Foszfor } \\
\text { szint }\end{array}$ & $\begin{array}{c}\text { SPAD } \\
\text { értékek }\end{array}$ & $\begin{array}{c}\text { Kálium } \\
\text { szint }\end{array}$ & $\begin{array}{c}\text { SPAD } \\
\text { értékek }\end{array}$ \\
\hline 0 & 46,842 & 0 & 53,164 & 0 & 55,307 \\
\hline 1 & 55,130 & 1 & 52,930 & 1 & 52,758 \\
\hline 2 & 55,586 & 2 & 55,205 & 2 & 55,924 \\
\hline 3 & 59,302 & 3 & 55,561 & 3 & 52,870 \\
\hline
\end{tabular}

Forrás: A szerző saját szerkesztése

A tápanyagszinteken mért SPAD értékek variancia analízisével nyomon követtük, hogy a bekövetkező változás eléri -e a szignifikáns különbség szintjét. A variancia értékeket a 4. táblázat szemlélteti.

\section{4. táblázat: A SPAD értékek variancia táblázata}

\begin{tabular}{|l|c|c|c|c|c|}
\hline & SQ & df & MS & F & Sig. \\
\hline Nitrogén & $\mathbf{1 7 4 7 , 7 2 3}$ & $\mathbf{3}$ & $\mathbf{5 8 2 , 5 7 4}$ & $\mathbf{1 1 , 6 2 0}$ & $\mathbf{, 0 0 0}$ \\
\hline Foszfor & $\mathbf{1 0 9 , 7 4 2}$ & $\mathbf{3}$ & $\mathbf{3 6 , 5 8 1}$ & $\mathbf{7 3 0}$ & $\mathbf{5 3 7}$ \\
\hline Kálium & $\mathbf{1 9 4 , 1 5 9}$ & $\mathbf{3}$ & $\mathbf{6 4 , 7 2 0}$ & $\mathbf{1 , 2 9 1}$ & $\mathbf{2 8 3}$ \\
\hline Hiba & $\mathbf{4 3 6 1 , 9 7 3}$ & $\mathbf{8 7}$ & $\mathbf{5 0 , 1 3 8}$ & & \\
\hline Összes & $\mathbf{2 9 2 1 8 6 , 3 0 6}$ & $\mathbf{9 7}$ & & & \\
\hline
\end{tabular}

Forrás: A szerzỏ saját szerkesztése

A varianciaanalízis alapján kijelenthető, hogy az elsö mérési alkalommal szignifikáns különbség csak a N szinteknek volt köszönhetö, a $\mathrm{P}$ és a $\mathrm{K}$ szintek növekedése nem okozott szignifikáns relatív klorofill tartalom növekedést a kukorica levelében.

A SPAD értékek regresszió analízise során megállapítottuk, hogy az értékek leginkább lineáris módon változnak. A növekvő nitrogén szintek egyértelmű relatív klorofill tartalom (SPAD érték) növekedést okoztak, bizonyítva azt, hogy a kukorica nitrogén ellátottsága és a kukorica növény klorofill tartalma között igen szoros az összefüggés. 


\section{1. ábra: A kukorica SPAD értékeinek, valamint a N-szintek lineáris regressziója}

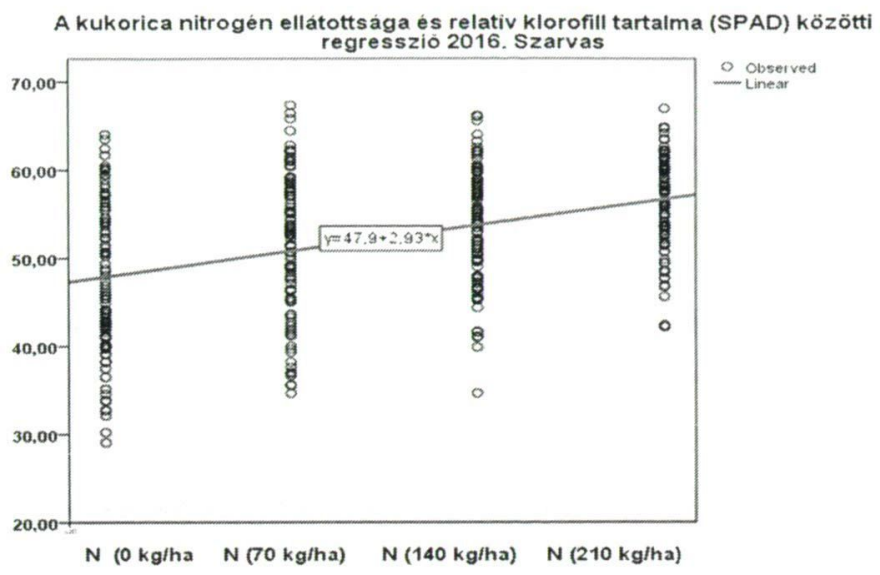

Forrás: A szerző saját szerkesztése

A kukorica termésátlaga nem csak a levél klorofill tartalmától, hanem a fotoszintetikusan aktív levélterület nagyságától is erősen függ. A kísérletünkben nyomon követtük a különböző tápanyagszinteken mérhető levélterületek nagyságát, és azt a termőterületre vetítve, levélterületi index $\left(\mathrm{LAI} \mathrm{m}^{2} / \mathrm{m}^{2}\right)$ értékben fejeztük ki, egyben elvégeztük az adatok regresszió analízisét is. (lásd: 2. ábra)

\section{2. ábra: A kukorica LAI $\left(\mathrm{m}^{2} / \mathrm{m}^{2}\right)$ értékeinek, valamint a $\mathbf{N}$-szintek lineáris regressziója}

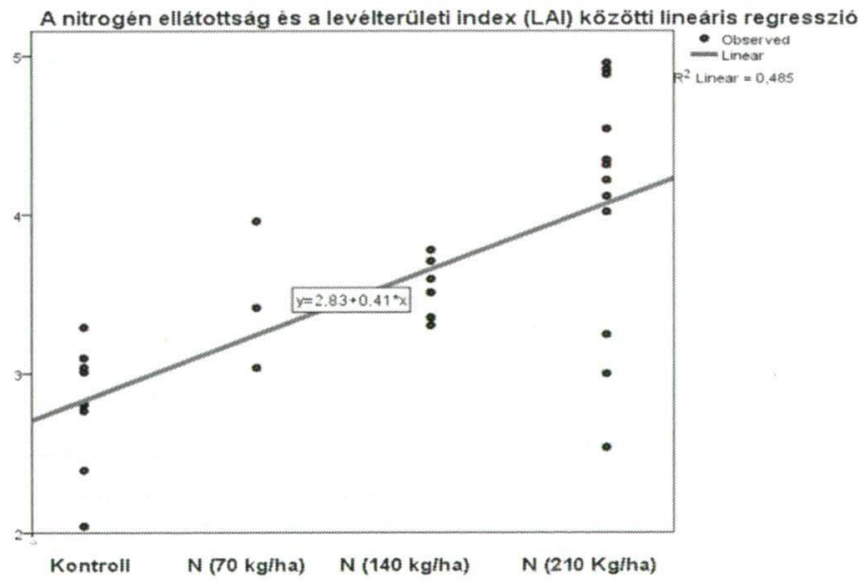

Forrás: A szerző saját szerkesztése

Az adatokból jól látható, hogy a levélterület növekedésére a legnagyobb hatással a nitrogén- és a foszforellátottság van. A kálium hatása rendkívül változó, amely a 
kísérleti terület eredetileg is magas kálium tartalmával indokolható. Kiemelkedően magas LAI érték növekedést mutatott a kísérlet során az N1 $(70 \mathrm{~kg} / \mathrm{ha})$ nitrogén dózis, illetve az N3 (210 kg/ha) nitrogén adag. (lásd: 5 . táblázat)

A levélterület változásra a nitrogénen kívül a foszforellátottság volt még nagy hatással, ahol a szignifikáns LAI érték növekedést a P2 $(80 \mathrm{~kg} / \mathrm{ha})$ foszfor adag biztosította. A kálium kezelés parcellái rendkívül szórt eredményeket adtak, a növekedés nem lineáris, a különbségek nem érték el a szignifikáns határt.

\section{5. táblázat: A kukorica LAI értékeinek alakulása különböző} tápanyagszinteken

\begin{tabular}{||l|l|l|r|l|l||}
\hline \multicolumn{7}{|c|}{$\mathbf{L A I}^{\mathbf{2}} / \mathbf{m}^{2}$} \\
\hline N0 & 2,81 & P0 & 2,99 & K0 & 3,15 \\
\hline N1 & 3,47 & P1 & 3,05 & K1 & 3,42 \\
\hline N2 & 3,54 & P2 & 3,83 & K2 & 4,14 \\
\hline N3 & 4,09 & P3 & 4,41 & K3 & 3,67 \\
\hline
\end{tabular}

Forrás: A szerzỏ saját szerkesztése

A terméseredmények szoros összefüggésben vannak mind a levélterület nagyságával, mind pedig a relatív klorofill tartalom értékekkel. Minél nagyobb egy növény relatív klorofill tartalma, és minél nagyobb levélterület vesz részt aktívan a fotoszintézis folyamatában, annál nagyobb szervesanyag termelésre képes, a potenciálisan előállítható termés igazolhatóan növekszik.

6. táblázat: A kukorica termésátlagának alakulása különböző tápanyagszinteken

\begin{tabular}{|l|l|l|l|l|l||}
\hline \multicolumn{7}{|c|}{ Termésátlag t/ha } \\
\hline N0 & 7,727 & P0 & 9,459 & K0 & 8,910 \\
\hline N1 & 8,809 & P1 & 8,446 & K1 & 8,718 \\
\hline N2 & 9,023 & P2 & 7,974 & K2 & 8,051 \\
\hline N3 & 9,080 & P3 & 8,759 & K3 & 8,959 \\
\hline
\end{tabular}

Forrás: A szerző saját szerkesztése

A táblázat eredményeiből jól látható, hogy a növekvő LAI értékek növekvő terméseredményekkel csak a nitrogén kezelések esetében párosultak. A foszfor és a kálium esetén a hatások eltérőek, egyértelmủ kísérleti hatás nem bizonyítható. Kijelenthetô tehát, hogy a nitrogén ellátás igen kedvezően befolyásolta a kialakuló SPAD értékeket, valamint a levélterület nagyságát, ami egy igen kedvező termésátlag növekedéssel járt. A foszfor és a kálium szerepe kisebb a termések kialakításában, azok leginkább a kukorica élettani folyamataira hatnak kedvezően. A termésátlagra gyakorolt hatás azért kisebb, mert az a különböző tápelemek kölcsönhatásán is alapul.

A terméseredmények variancia analízise is ezt támasztotta alá, a legerőteljesebb szignifikáns különbséget a nitrogén hatására tapasztaltuk. (lásd: 7. táblázat) 
7. táblázat: A kukorica terméseredményeinek variancia analízise 2016.

\begin{tabular}{|l|l|l|l|l|l|}
\hline & \multicolumn{1}{|c|}{ SQ } & \multicolumn{1}{c|}{ df } & \multicolumn{1}{c|}{ MS } & \multicolumn{1}{c|}{ F } & \multicolumn{1}{c|}{ Sig. } \\
\hline Corrected Model & $138,733^{\mathrm{a}}$ & 9 & 15,415 & 3,475 &, 001 \\
Intercept & 14397,596 & 1 & 14397,596 & 3245,843 &, 000 \\
Nitrogén & 57,656 & 3 & 19,219 & 4,333 & $\mathbf{0 0 6}$ \\
Foszfor & 55,851 & 3 & 18,617 & 4,197 & $\mathbf{0 7 7}$ \\
Kálium & 25,226 & 3 & 8,409 & 1,896 & $\mathbf{1 3 2}$ \\
Error & 807,298 & 182 & 4,436 & & \\
Total & 15343,628 & 192 & & & \\
Corrected Total & 946,031 & 191 & & & \\
\hline
\end{tabular}

Forrás: A szerző saját szerkesztése

A kísérletünkben a különböző tápanyagok eltérő dózisainak hatását vizsgáltuk, a kukorica különböző paramétereire. Jelen dolgozatban nem volt lehetőség a tápanyagok közötti interakciók vizsgálatára, azonban a fö tápelemek hatását és azok a reakcióit, a kísérletben igazolni tudtuk.

\section{Következtetések, összegzés, záró megjegyzések, záró gondolatok}

Kísérletünkben monokultúrás kukorica tápanyag-reakcióit vizsgáltuk a növény relatív klorofill tartalmára, levélterületének változására. Ezen felül vizsgáltuk a levélterület és a SPAD értékek, valamint a terméseredmények közötti összefüggéseket.

Megállapítottuk, hogy a kísérletünkben a legnagyobb hatást a vizsgált három tápelem közül a nitrogén mutatta, kisebb hatást a foszfor és a kálium esetén tapasztaltunk. A vizsgált paraméterek közül szignifikáns különbségeket az esetek döntő részében csak a nitrogén kezelések esetén tudtunk igazolni, a foszfor és a kálium esetében a hatások leginkább trend jellegủek, a szignifikancia határát csak kis arányban érték el.

Bebizonyítottuk, hogy a növekvő levélterület és a növekvő relatív klorofill tartalom magasabb termésátlagok kialakulását eredményezi, az összefüggés szoros pozitív korrelációt mutat, a regresszió analízis alátámasztotta a kiindulási hipotézisünket.

\section{Köszönetnyilvánítás}

A publikáció az EFOP-3.6.1-16-2016-00016 „SZIE Szarvasi Campusának kutatási és képzési profiljának specializálása intelligens szakosodással: mezőgazdasági vízgazdálkodás, hidrokultúrás növénytermesztés, alternatív szántóföldi növénytermesztés, ehhez kapcsolódó precíziós gépkezelés fejlesztése." címü projekt támogatásával jött létre.

\section{Irodalomjegyzék}

Berzsenyi Z., Lap D. Q.: 2001. A kukorica N-ellátottságának monitoringja SPAD-502 típusú klorofill mérővel. Martonvásár: az MTA Mezőgazdasági Kutatóintézetének Közleményei, 13 (1): 7. 
Futó Z. (2003): A levélterület hatása a kukorica terméseredményére trágyázási kísérletben. Növénytermelés, Tom. 52 (3-4): 317-328.

Széles A. V. (2008): The effect of crop year and fertilization on the interaction between the spad value and yield of maize (Zeamays L.) within non-irrigated conditions. Cereal Research Communications. 36 (Suppl. 5): 1367-1370. 14 ref. 7th Alps-Adria Scientific Workshop, Stara Lesna, Slovakia.

Széles A. V., Megyes A., Nagy J. (2011): Effect of N fertilisation on the chlorophyll content and grain yield of maize indifferent crop years. Növenytermelés. 2011. 60. Supplement, 161-164. 6 ref. 10th Alps-Adria Scientific Workshop.

Tóth Z., Sárdi K., Horváth E. D. (2014): Evaluation of the relationship between spad chlorophyll values and leaf nitrogen contents of maize. Proceedings of the 13th ESA Congress. 25-29th august 2014. Debrecen, Hungary, 167-168. 